Journal of Business and Tourism

Volume 06 Number 01

January - June, 2020

\title{
Country Governance and Corporate Governance as determinants of Firm Efficiency; Empirical Study of Pakistan
}

\author{
Muhammad Nisar Khan \\ Lecturer at Bacha Khan University, Charsadda \\ PhD scholar at Abdul Wali Khan University, Mardan. \\ Dr. Muhammad Ilyas \\ Lecturer, IBL, Abdul Wali Khan University, Mardan \\ Milyas_85@awkum.edu.pk \\ Dr. Saima Urooge \\ Assistant Professor, Department of Economics, \\ Islamia College University, Peshawar \\ saimaurooge@icp.edu.pk
}

\begin{abstract}
Financial Crisis Inquiry Commission (FCIC) report of 2011 state that financial crises and failure of large corporation is due to weak governance system. Therefore, governments and regulatory bodies are convinced to ensure effective $C G$ practices and strict regulatory requirements must be imposed. The primary aim of this research is to examine the effect of corporate governance both at country and firm-level on the firm's efficiency of Pakistani listed non-financial firms. The empirical analyses consist of two parts. Initially firm efficiencies such as overall technical efficiency, Pure Technical efficiency and Scale efficiency are measured through Data Envelopment Analysis (DEA) technique over a 10 years' period from 2008 to 2017.These efficiency scores are used as proxies for firm performance. In the second stage, CGboth at firm and country level are used as independent variables to examine its impact on firm efficiencies scores. The results findings support the theoretical justifications that efficient system of CG and regulatory system ensures disclosures. These disclosures not only enhance accounting information quality but also help in reducing agency cost which in return improve investors protection. Thus, managers tend to take decisions in the best interest of shareholder by utilizing firm resources efficiently and effectively and as a result enhance firm efficiency.
\end{abstract}

Key words: corporate governance, country governance, firm efficiency and panel data

\section{Introduction}

The collapses of high profile corporations due to poor systems of monitoring and accountability has taken the issue of governance into the notice that there should be 
strong regulatory system in the corporations (Claessens \& Yurtoglu, 2012; Davies \& Schlitzer, 2008). This worldwide failure of corporations has increased the attention of governments and regulators towards corporate governance reforms and regulation all around the globe. Published reports on these failures and scandals from the last two decades provide evidence on the importance of a strong regulatory system, such as Cadbury Report (1992), Peters Report (1997),Committee (1995) Vienot Report (1995), Preda Report (1999) and Cardon Report (1998). There are many determinants of CG in a country such as de facto realities of a country's corporate environment, the regulatory and legal structure which states the role and responsibilities of stakeholders; article of association of each firm. Pakistani code of CG was highly influenced by Anglo-American model. There is an interesting case while studying the effect of CG code, the adopted system of CG is quite in contrast to the de facto realities (Tariq \& Abbas, 2013). Due to pyramid and cross shareholdings ownership structure, Pakistani capital market is characterized as concentrated ownership structure (Claessens, Djankov, \& Lang, 2000). Family businesses, debts from banks are preferred as compared to equity issuance for financing purposes, also an inactive and underdeveloped market for corporate control are some of weak characteristics of Pakistan capital market.

Prior literature provide evidence that good CG leads to better performance, benefiting shareholders through access to capital (Reddy, Locke, \& Scrimgeour, 2010). This literature also reports that distribution of free cash flows among shareholders instead of being expropriated (Jensen, 1986; La Porta, Lopez- de- Silanes, Shleifer, \& Vishny, 2002) reduces the management control rights and helps in increasing the chances that managers highly likely make investment decisions that can increase shareholders value (Shleifer \& Vishny, 1997). similarly, poor regulatory structure can increase the cost of compliance for businesses and all other groups, cause uncertainty and unnecessary complexity as to regulatory obligations and hence reduction in government effectiveness in achieving its objectives (OECD, 2008). Thus, compatibility among CG system corporate culture and capital market facilitate the businesses and hence improve firms' performance and efficiency. For obtaining efficiency, two approaches are used. These approaches are parametric and non-parametric approaches. There are some prior assumptions for parametric approach before measuring the efficiency (Färe \& Primont, 1993). On the other hand, there are no assumptions for non-parametric approaches. One of the non-parametric approaches is (DEA) that takes different inputs and outputs to estimate the efficiency. This study used non-parametric method of measuring firm efficiency.

The literature on CG suggest that firm level governance affect firm performance. Recent studies on governance research suggest that country level governance in which the firms operates may have better explanations, which may lead to better discuss the association among firm level governance and performance. It is important to note here that this research is an attempt to take CG both at firm and country level into account to examine its effect on firm efficiency in selected listed firms of Pakistan Stock Exchange (PSX) 
instead of examining its moderating effect among firm level governance and firm performance. To capture the association between CG both at firm and country level and firm efficiency, this research uses panel data analysis as the nature of the data is panel. The results reveal that efficient regulatory environment of the country and effective corporate governance system help in increasing firm efficiency.

\section{Literature Review}

In the business world, CG has got much importance because of failures of high-profile business and world financial crises. Due to recent financial crises importance of CG has been increased in avoiding or protecting corporate failures in future. Previous literature has largely discussed CG and performance relationship in many research areas. Still prior literature has diverted a little attention of researchers in emerging markets particularly Asian markets, as CG systems in developing countries are considered as concentrated ownership structure and also weak country-level governance (Al-Mustafa, 2017).

Firstly, as firms have both social and economic characteristics, therefore CG practices cannot be based or explained on single theoretical assumption. Furthermore, agency theory only based the idea where managers make their efforts to achieve the primary objective of firms which is wealth maximization (Jensen \& Meckling, 1976). Similarly, others have different views about the objective of business firms. Such as, agency theory has further extended by stakeholders' theory by adding other parties in the nexus of contract of firms to achieve firm objective (Donaldson \& Preston, 1995). Another perspective of the firm is that how they are contributing to the welfare of stakeholders.

Based on economic, legal and political background in the countries their CG practices varies or even firms within the country in which it operates. According to Denis and McConnell (2003)countries having strong legal, political and economic environment like USA and UK depends on strong investors protection. In contrast, developing countries such as Pakistan are characterized by having weak IP and thus firms depend on concentrated ownership as framework for IP where legal protection environment is weak. Finally, countries across the world started to revised their CG codes fueled by the corporate scandals. Which can ultimately help in improving CG practices of the businesses in these countries. These are the points which are added to the CG complex nature in making it an important topic of discussion in management research.

One reason is that shareholders mainly rely on two broad firm level and country level governance categories in mitigating agency problem. Literature reports that national governance system can be linked to legal system, rule of law, investors protection and all other takeover market instruments treating these variables as extreme exogenous variables. Gillan (2006) classify these variables as country level governance variables. On the other hand, firm level CG are endogenous variables as these variables are related directly to the environment of the firms such as board of directors (Jensen, 1993), and ownership concentration such as controlling shareholders (Jensen \& Meckling, 1976) and can be controlled through different policies related to firm (Lemmon \& Lins, 2003). 
However, researchers such as Demsetz and Lehn (1985) examine this association and report that ownership structure behave as endogenous in equilibrium of financial performance and a firm's other unobserved characteristics. Furthermore, Demsetz and Villalonga (2001) states that investors usually buy shares of those companies which offer higher rate of return. In these standpoints, corporate performance and ownership structure are simultaneously determined. The same argument is supported by Wintoki, Linck, and Netter (2012). Recent studies of CG research, such as Nguyen et al. (2015) and Filatotchev et al. (2013) highlight the country level governance importance in minimizing the agency cost. As a result, it improves the financial performance of firms working in such quality national governance environment. National governance quality helps in reducing production and transactions costs and minimizing the risk, as a result, improve firm profitability (Ngobo \& Fouda, 2012).

Earlier literature reports a direct relationship among national governance quality and firm performance. Ngobo and Fouda (2012) and Saona and San Martín (2016) report a positive association between country level governance quality and firm performance. Furthermore, some researchers argue that country governance quality may help in moderating or enhancing the relationship among firm level governance and firm performance as examined by (Nguyen et al., 2015). Kumar and Zattoni (2013) states that firm and country level governance system are inter-related with each other in development global CG theory. Moreover, Rose (2016) suggests that a firm's compliance with country level CG codes solely depends on their institutional environment. Richter and Weiss (2013) argue that institutional environment in which the firms operate has a high effect on ownership concentration. Sobel (2003) states that better national governance system is highly related with better lending and great access to capital. Hail and Leuz (2006)/provide evidence in their study that country level governance intensiveness and broad regulatory environment has a negative significant association with cost of capital. La Porta et al. (2002) report that a country where there is strong investors protection and high national governance and legal system, firms in those countries enjoy high valuation. From the above literature, is can be suggested that national governance quality has a number of implications on firm's activities and as a result on its performance. Thus, study is carried out to investigate the effect of country level governance quality on firm in the context of Pakistan.

The association between national governance structure and and firm performance in emerging economies remain an important open question (Nguyen et al., 2015). Based on these theoretical propositions and varying empirical results, the following theoretical/conceptual framework is proposed;

\section{Framework of Stage 2.}

After calculating firm efficiencies through DEA. Figure below shows the conceptual framework of $\mathrm{CG}$ at firm-level and country-level (WGI) with firm efficiency which explain that the study focus on investigating the impact of CGI and WGI on FE (OTE, PTE and SE). 


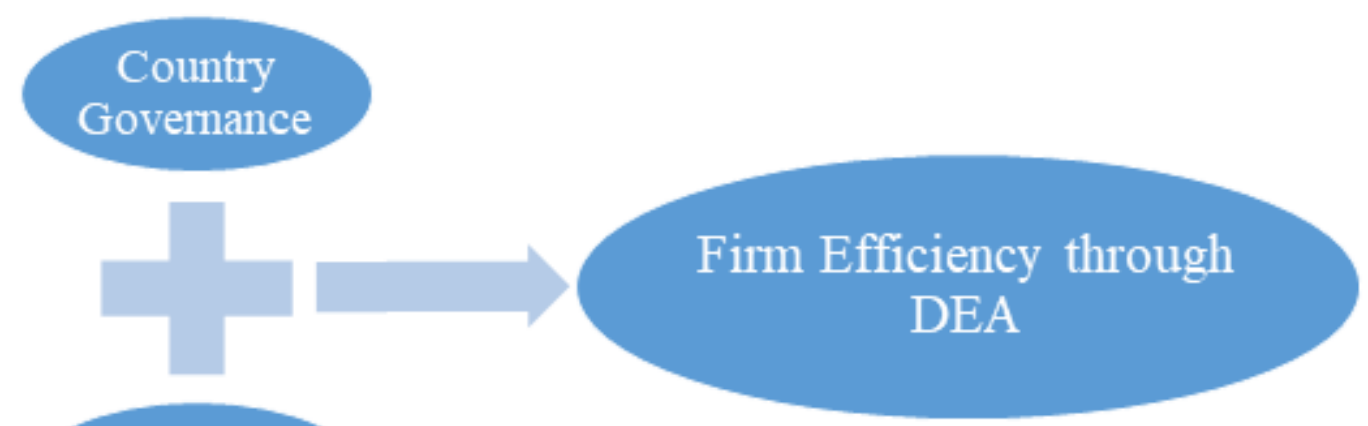

\section{Corporate}

\section{Governance}

\section{Data Collection and Methodology}

Population of this research is listed non-financial firms on PSX.A total of 136 firms are selected on the basis of data availability over aperiod of 2008 to 2017.

The reason to select this sample size and sample period is that some listed companies' annual reports are not available on their websites. Those firms are excluded from the sample size whose data for CG was not available on their annual reports.data for CG and firm efficiency is collected and data for country governance is collected from Kaufmann et al. (2011) World Governance Indicators for Pakistan taken from the world bank website.

This study attempts to use different models of data analysis to increase the accuracy of the results (Pornupatham, 2006). This study proposes to use univariate (descriptive statistics) bivariate analysis (Correlation analysis) and multivariate analysis (panel regression analysis) to investigate the association of dependent (Firm Efficiency) and independent variables (Country Governance and Corporate governance) after controlling for Size, BETA, Growth, leverage, GDP growth, Financial Crises, and Operating cash flows.

The proposed three models are given below;

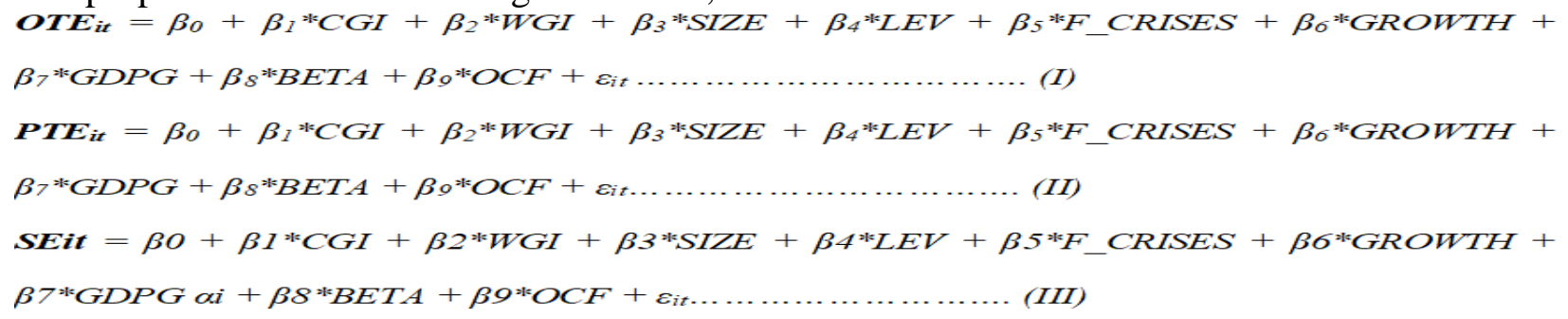


Table 1 shows descriptive statistics

\begin{tabular}{cccccccc}
\hline & Mean & Median & Maximum & Minimum & Std. Dev. & Skewness & Kurtosis \\
\hline OTE & 0.607 & 0.557 & 1.000 & 0.460 & 0.106 & 0.245 & 3.007 \\
PTE & 0.652 & 0.609 & 1.000 & 0.509 & 0.170 & 0.261 & 3.433 \\
SE & 0.554 & 0.521 & 1.000 & 0.410 & 0.125 & 0.140 & 3.093 \\
CGI & 78.074 & 78.572 & 100.000 & 57.158 & 7.534 & -0.033 & 2.869 \\
WGI & -0.283 & -0.604 & 0.846 & -0.973 & 0.629 & 0.859 & 2.270 \\
F_SIZE & 15.823 & 15.702 & 19.840 & 11.907 & 1.507 & 0.339 & 3.143 \\
LEV & 1.360 & 1.078 & 3.678 & -1.188 & 1.177 & 0.234 & 2.914 \\
GROWTH & 12.273 & 12.093 & 16.099 & 8.010 & 1.968 & 0.299 & 2.945 \\
BETA & 0.737 & 0.740 & 2.070 & -0.990 & 0.615 & -0.131 & 2.914 \\
F_CRISES & 0.298 & 0.000 & 1.000 & 0.000 & 0.458 & 0.881 & 1.776 \\
GDPG & 3.449 & 3.507 & 4.833 & 1.607 & 1.150 & -0.320 & 1.744 \\
OCF & 1.183 & 0.066 & 3.108 & -1.801 & 1.607 & 0.753 & 2.270 \\
\hline
\end{tabular}

OTE PTE and SE are dependent variables.

CGI is corporate governance index and WGI world governance indicators for Pakistan. 


\section{Correlation Matrix}

Correlation matric is used to check the relationship between variables. Below given tables shows the association between variables.

Table 2 shows the correlation of variables

\begin{tabular}{|c|c|c|c|c|c|c|c|c|c|c|c|c|}
\hline & OTE & PTE & SE & CGI & WGI & $\underset{\mathbf{E}}{\mathbf{F} \_\mathbf{S I Z}}$ & LEV & $\begin{array}{c}\text { GROWT } \\
\text { H }\end{array}$ & $\begin{array}{c}\text { BET } \\
\text { A }\end{array}$ & $\begin{array}{c}\text { F_CRISE } \\
\mathrm{S}\end{array}$ & $\begin{array}{c}\text { GDP } \\
\text { G }\end{array}$ & $\begin{array}{c}\text { OC } \\
\text { F }\end{array}$ \\
\hline \multicolumn{13}{|l|}{ OTE } \\
\hline PTE & $0.63 *$ & & & & & & & & & & & \\
\hline SE & $0.84 *$ & $0.49 *$ & & & & & & & & & & \\
\hline CGI & $0.11 *$ & $0.09 *$ & $0.11 *$ & & & & & & & & & \\
\hline WGI & $0.13 *$ & $0.05^{*}$ & $0.14 *$ & 0.04 & & & & & & & & \\
\hline F_SIZE & $0.02 *$ & $0.14 *$ & 0.03 & $0.08 *$ & $0 . \overline{06 *}$ & & & & & & & \\
\hline LEV & $-0.13^{*}$ & $-0.17 *$ & $-0.11 *$ & $0.09 *$ & -0.01 & $0.13 *$ & & & & & & \\
\hline $\begin{array}{c}\text { GROWT } \\
\mathrm{H}\end{array}$ & $0.21 *$ & $0.23 *$ & $0.18^{*}$ & $0.09 *$ & $0.17 *$ & $0.63^{*}$ & $0.07 *$ & & & & & \\
\hline BETA & $-0.16^{*}$ & $-0.12^{*}$ & $-0.16^{*}$ & $0.07 *$ & 0.01 & $0.29 *$ & -0.01 & $0.09 *$ & & & & \\
\hline $\begin{array}{c}\text { F_CRISE } \\
S\end{array}$ & $0.04 * *$ & $-0.05^{*}$ & $0.04 * *$ & $0.15 *$ & $0.25^{*}$ & $-0.13^{*}$ & $0.14 *$ & $-0.08 *$ & $-0.14 *$ & & & \\
\hline GDPG & $0.05^{*}$ & 0.01 & $0.07 *$ & $0.07 *$ & $0.33^{*}$ & $0.05^{* *}$ & $\begin{array}{c}- \\
0.08 *\end{array}$ & -0.04 & $0.06^{*}$ & $-0.19 *$ & & \\
\hline $\mathrm{OCF}$ & $0.08^{*}$ & $\begin{array}{c}0.04 * \\
*\end{array}$ & $0.08 *$ & -0.03 & $0.10 *$ & $-0.11 *$ & $0.05^{-}$ & -0.02 & -0.01 & 0.02 & 0.03 & \\
\hline
\end{tabular}

$*(* *)$ represent the level of significance at $5 \%$ and $10 \%$ respectively 
Table 3 shows result of VIF test for multicollinearity

\begin{tabular}{ccc}
\hline Variables & VIF & $\mathbf{1 / V I F}$ \\
\hline CGI & 1.06 & 0.943 \\
WGI & 1.47 & 0.680 \\
F_Size & 2.06 & 0.485 \\
Lev & 1.07 & 0.935 \\
Growth & 1.95 & 0.513 \\
Beta & 1.15 & 0.870 \\
F_Crises & 1.28 & 0.781 \\
GDPG & 1.32 & 0.758 \\
OCF & 1.02 & 0.980 \\
\hline Mean VIF & 1.38 & \\
\hline
\end{tabular}

From the above given table, it can be easily observed that there is no multicollinearity among the variables as the VIF mean values are less than 10 in all three models.

\section{Test for Autocorrelation}

Autocorrelation in the data can affect the standard errors which in return affect the overall results(Drukker, 2003). Durbin-Watson test is used for detecting autocorrelation. Given below results shows the problem of autocorrelation in all models as Durbin-Watson test for all three models is lower than 2.

From below results, it is stated that there is autocorrelation problem in all model of dependent variables and thus parametric test cannot be applied on the data.

Table 4 shows Autocorrelation results

\begin{tabular}{lc}
\hline \multicolumn{1}{c}{ Model } & Durbin-Watson Statistics \\
\hline Model 1 (OTE with CGI and WGI) & 0.796490 \\
Model 2 (PTE with CGI and WGI) & 0.659289 \\
Model 3 (SE with CGI and WGI) & 0.498339 \\
\hline
\end{tabular}

Model specification tests

Given table below shows models specification to choose the suitable model for panel data analysis for this study.

Table 5 shows the test for model specification 


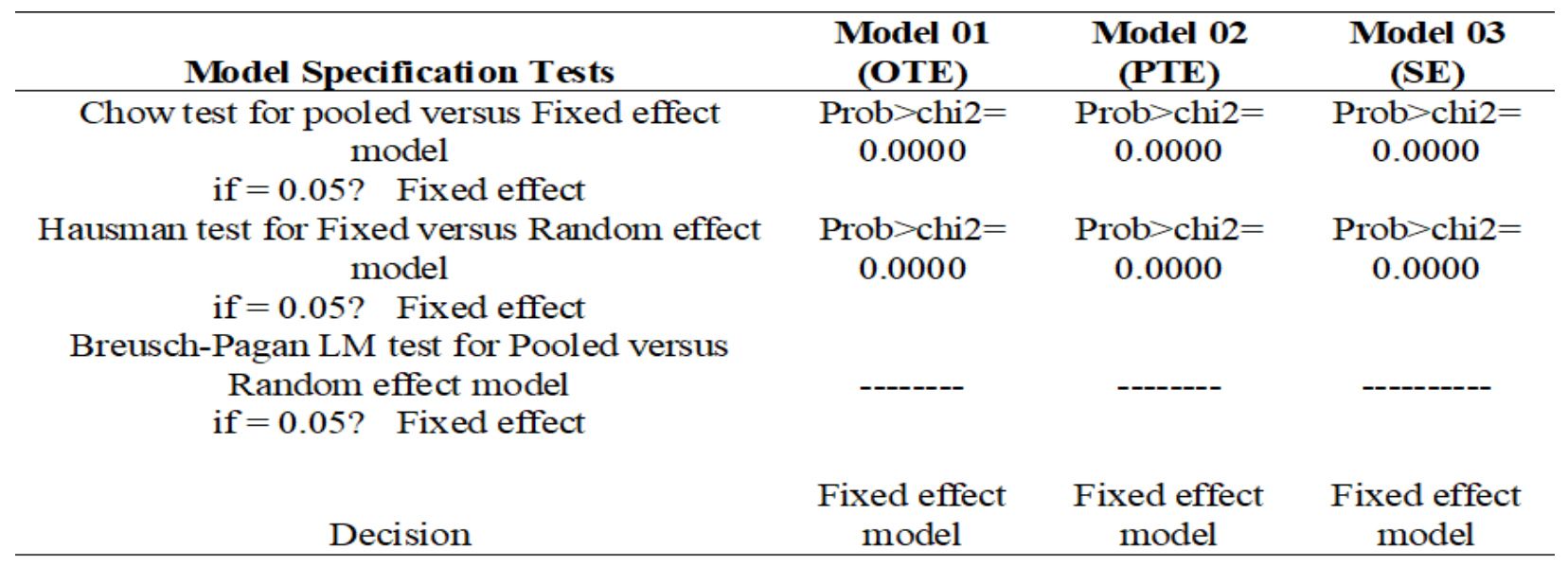

Result of Fixed effect model

Table 6 Results of FEM of OTE with CGI and WGI.

\begin{tabular}{ccccc}
\hline Variable & Coefficient & Std. Error & t-Statistic & Prob. \\
\hline C & -0.098 & 0.0408 & -2.396 & 0.017 \\
CGI & 0.001 & 0.0004 & 3.549 & 0.000 \\
WGI & 0.014 & 0.0052 & 2.623 & 0.009 \\
F_SIZE & 0.004 & 0.0026 & 1.735 & 0.083 \\
LEV & -0.012 & 0.0024 & -5.026 & 0.000 \\
GROWTH $)$ & 0.014 & 0.0019 & 7.263 & 0.000 \\
F_CRISES & -0.011 & 0.0067 & -1.717 & 0.086 \\
BETA & -0.030 & 0.0047 & -6.470 & 0.000 \\
OCF & 0.000 & 0.0001 & 3.338 & 0.001 \\
GDPG & 0.002 & 0.0027 & 0.714 & 0.475 \\
\hline R-squared & 0.605 & & & \\
Adjusted R-squared & 0.558 & & & \\
F-statistic & 22.624 & & & \\
Prob(F-statistic) & 0.0000 & & & \\
\hline
\end{tabular}

Table 7 Results of FEM (Pure Technical Efficiency).

\begin{tabular}{ccccc}
\hline Variable & Coefficient & Std. Error & t-Statistic & Prob. \\
\hline C & -41.734 & 8.666 & -4.816 & 0.0000 \\
CGI & 0.230 & 0.079 & 2.919 & 0.0036 \\
WGI & 3.276 & 1.107 & 2.960 & 0.0031
\end{tabular}




\begin{tabular}{|c|c|c|c|c|}
\hline SIZE & 1.152 & 0.545 & 2.114 & 0.0347 \\
\hline LEV & -3.930 & 0.503 & -7.819 & 0.0000 \\
\hline GROWTH & 2.568 & 0.408 & 6.301 & 0.0000 \\
\hline F_CRISES & -0.340 & 1.419 & -2.239 & 0.0409 \\
\hline BETA & -6.232 & 1.000 & -6.234 & 0.0000 \\
\hline $\mathrm{OCF}$ & 0.072 & 0.031 & 2.353 & 0.0188 \\
\hline GDPG & 0.029 & 0.574 & 0.051 & 0.9596 \\
\hline R-squared & 0.561 & & & \\
\hline Adjusted R-squared & 0.509 & & & \\
\hline F-statistic & 23.033 & & & \\
\hline Prob(F-statistic) & 0.0000 & 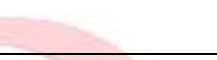 & & \\
\hline \multicolumn{5}{|c|}{ Table 8Results of FEM(Scale Efficiency). } \\
\hline Variable & Coefficient & Std. Error & t-Statistic & Prob. \\
\hline $\mathrm{C}$ & -0.0130 & 0.09681 & -1.34481 & 0.1789 \\
\hline CGI & 0.0293 & 0.0876 & 3.342162 & 0.0009 \\
\hline WGI & 0.0414 & 0.0123 & 3.362325 & 0.0008 \\
\hline SIZE & -0.0480 & 0.6090 & -0.78904 & 0.4302 \\
\hline LEV & -0.0242 & 0.05620 & -4.30059 & 0.0000 \\
\hline GROWTH & 0.0243 & 0.0454 & 5.355901 & 0.0000 \\
\hline F_CRISES & -0.0277 & 0.0159 & -1.7466 & 0.0809 \\
\hline BETA & -0.0717 & 0.0112 & -6.41524 & 0.0000 \\
\hline $\mathrm{OCF}$ & 0.0869 & 0.0349 & 2.492045 & 0.0128 \\
\hline GDPG & 0.0641 & 0.0640 & 1.002714 & 0.3162 \\
\hline R-squared & 0.6100 & & & \\
\hline Adjusted R-squared & 0.5636 & & & \\
\hline F-statistic & 18.1124 & & & \\
\hline Prob(F-statistic) & 0.00000 & & & \\
\hline
\end{tabular}

Among the three regression models, the first model is used to explore the effect of CG both at macro (country) and micro(firm level) on overall technical efficiency of firms taking other independent variables as control variables. Results show a positive significant effect of CG at firm level on firm efficiency at the significance level of $1 \%$. Which confirm the hypothesis. Same results are reported by (Dedu and Chitan, 2013;Andreou, Louca and Panayides, 2014; Gupta and Sharma, 2014). Results recommend that in order to provide protection to investors, protect the interest of shareholders, managers and all other stakeholders, to minimize the agency problem to align the interests of all stakeholders and, thus producing long-lasting firm efficiency, the 
corporate governance play an important role in this regard (Cadbury, 1992; La Porta et al. 1997; Diacon and O'sullivan, 1995; FRC, 2014). Similarly, this study focuses on the effect of CG at country level on firm efficiency as it helps in reducing agency problem and hence increase firm performance (efficiency). Hence table 6shows country level governance and its effect on firm efficiency during the period of 2008-2017 in Pakistan. hypothesis 2 was formulated to states that good quality of national level governance practices would increase the firm efficiency (performance). In order to explore the relationship of CG at country level and firm efficiency, a composite variable derived from Kaufman et al., 2011 six world governance indicators are taken as proxy for national level governance variable. The regression analysis results show that the coefficient of CG at country level (WGI) shows a positive and significant effect on FE at $1 \%$ level. It is suggested that not only $\mathrm{CG}$ helps in reducing agency problem but $\mathrm{CG}$ at country level also play vital role in minimizing the agency problem, as a result, performance increases (Aslan \& Kumar,2012). These results are in line to the stated hypothesis 2 which states that country level governance has a significant effect on firm efficiency. The results are also in line with the results of Nguyen et al., (2015). These results are also supported by the existing literature, that countries having better country level governance encourage low risk investments which in return helps in high profitability and decrease firm's performance variability (Ngobo \& Fouda, 2012).

\section{Conclusion of the study}

The objectives of the study are to calculate firm efficiency through DEA and to investigate the effect of firm level and country level CG on firm efficiency. Furthermore, the motivation comes from the recent call to add CG at country level effect on firm efficiency in emerging capital markets such as Pakistan. Total of 1360 firm-years observations of non-financial listed firms are used to investigate the stated hypotheses and achieve objectives. As the CG in emerging markets such as Pakistan is characterized by controlling shareholders which is the determinant of firm performance. The result of the study confirmed that better CG practices play important role in enhancing firm efficiency of sample firms. Moreover, the study has included country level governance mechanism to test its effect on firm efficiency and results revealed that firm level as well as CG at country level helps in mitigating agency problem La Porta et al. (2002). The results confirm the two theoretical assumption such as agency theory and institutional theory in explaining the governance and firm efficiency relationship in the context of Pakistan.

\section{References}

Andreou, P. C., Louca, C., \& Panayides, P. M. (2014). Corporate governance, financial management decisions and firm performance: Evidence from the maritime industry. Transportation Research Part E: Logistics and Transportation Review, 63, 59-78. 
Aslan, H., 7 Kumar, P. (2014). National governance bundles and corporate agency costs: A cross- country analysis. Corporate governance: an international review, 22(3), 230-251.

Cadbury, A. (1992). Report of the committee on the financial aspects of corporate governance (Vol. 1): Gee.

Committee, V. (1995). The Boards of Directors of Listed Companies (Vienot Report). Paris: $C N P F-A F E P$.

Claessens, S., Djankov, S., 7 Lang, L. H. (2000). The separation of ownership and control in East Asian corporations. Journal of financial Economics, 58(1-2), 81-112.

Claessens, S., Tong, H., and Wei, S.-J. (2012). From the financial crisis to the real economy: Using firm-level data to identify transmission channels. Journal of International Economics, 88(2), 375-387.

Claessens, S., \& Yurtoglu, B. (2012). Corporate governance and development: an update: World Bank.

Davies, M., \& Schlitzer, B. (2008). The impracticality of an international "one size fits all" corporate governance code of best practice. Managerial Auditing Journal, 23(6), 532-544.

Dedu, V., \& Chitan, G. (2013). The influence of internal corporate governance on bank performance-an empirical analysis for Romania. Procedia-Social and Behavioral Sciences, 99, 1114-1123.

Demsetz, H., \& Lehn, K. (1985). The structure of corporate ownership: Causes and consequences. Journal of political economy, 93(6), 1155-1177.

Demsetz, H., and Villalonga, B. (2001). Ownership structure and corporate performance. Journal of corporate finance, 7(3), 209-233.

Drukker, D. M. (2003). Testing for serial correlation in linear panel-data models. The stata journal, 3(2), 168-177.

Färe, R., \& Primont, D. (1993). Measuring the efficiency of multiunit banking: An activity analysis approach. Journal of Banking \& Finance, 17(2-3), 539-544.

Filatotchev, I., Jackson, G., \& Nakajima, C. (2013). Corporate governance and national institutions: A review and emerging research agenda. Asia Pacific Journal of Management, 30(4), 965-986.

Gillan, S. L. (2006). Recent developments in corporate governance: An overview: Elsevier.

Gupta, P., and Sharma, A. M. (2014). A study of the impact of corporate governance practices on firm performance in Indian and South Korean companies. ProcediaSocial and Behavioral Sciences, 133, 4-11.

Hail, L., and Leuz, C. (2006). International differences in the cost of equity capital: Do legal institutions and securities regulation matter? Journal of Accounting Research, 44(3), 485-531. 
Jensen, M. C., \&d Meckling, W. H. (1976). Theory of the firm: Managerial behavior, agency costs and ownership structure. Journal of financial Economics, 3(4), 305360.

Jensen. (1986). Agency costs of free cash flow, corporate finance, and takeovers. The American economic review, 76(2), 323-329.

Jensen, G. R., Solberg, D. P., \& Zorn, T. S. (1992). Simultaneous determination of insider ownership, debt, and dividend policies. Journal of financial and quantitative analysis, 27(2), 247-263.

Kaufmann, D., Kraay, A., \& Mastruzzi, M. (2011). The worldwide governance indicators: methodology and analytical issues. Hague Journal on the Rule of Law, 3(2), 220-246.

Kumar, P., \& Zattoni, A. (2013). How much do country-level or firm-level variables matter in corporate governance studies?

La Porta, R., Lopez- de- Silanes, F., Shleifer, A., and Vishny, R. (2002). Investor protection and corporate valuation. The journal of finance, 57(3), 1147-1170.

Le, T. V., and Buck, T. (2011). State ownership and listed firm performance: a universally negative governance relationship? Journal of Management \& Governance, 15(2), 227-248.

Mayer, C. (1997). Corporate governance, competition, and performance. Journal of Law and Society, 152-176.

Ngobo, P. V., \& Fouda, M. (2012). Is 'Good'governance good for business? A crossnational analysis of firms in African countries. Journal of World Business, 47(3), 435-449.

Nguyen, T., Locke, S., \& Reddy, K. (2015). Ownership concentration and corporate performance from a dynamic perspective: Does national governance quality matter? International Review of Financial Analysis, 41, 148-161.

O'Sullivan, N., \& Diacon, S. (1999). Internal and external governance mechanisms: evidence from the UK insurance industry. Corporate governance: an international review, 7(4), 363-373.

Pornupatham, S. (2006). An empirical examination of earnings management, audit quality and corporate governance in Thailand: perceptions of auditors and audit committee members. University of Wales, Cardiff.

Tariq, Y. B., and Abbas, Z. (2013). Compliance and multidimensional firm performance: Evaluating the efficacy of rule-based code of corporate governance. Economic Modelling, 35, 565-575.

Reddy, K., Locke, S., \& Scrimgeour, F. (2010). The efficacy of principle-based corporate governance practices and firm financial performance: An empirical investigation. International Journal of Managerial Finance, 6(3), 190-219.

Richter, A., \& Weiss, C. (2013). Determinants of ownership concentration in public firms: The importance of firm-, industry-and country-level factors. International Review of Law and Economics, 33, 1-14. 
Rose, C. (2016). Firm performance and comply or explain disclosure in corporate governance. European Management Journal, 34(3), 202-222.

Saona, P., \& San Martín, P. (2016). Country level governance variables and ownership concentration as determinants of firm value in Latin America. International Review of Law and Economics, 47, 84-95.

Shleifer, A., \& Vishny, R. W. (1997). A survey of corporate governance. The journal of finance, 52(2), 737-783.

Sobel, A. C. (2003). National governance and global lending. Journal of International Management, 9(3), 287-304.

Wintoki, M. B., Linck, J. S., \& Netter, J. M. (2012). Endogeneity and the dynamics of internal corporate governance. Journal of financial Economics, 105(3), 581-606.

Yoo, T., \& Jung, D. K. (2015). Corporate governance change and performance: The roles of traditional mechanisms in France and South Korea. Scandinavian Journal of Management, 31(1), 40-53.

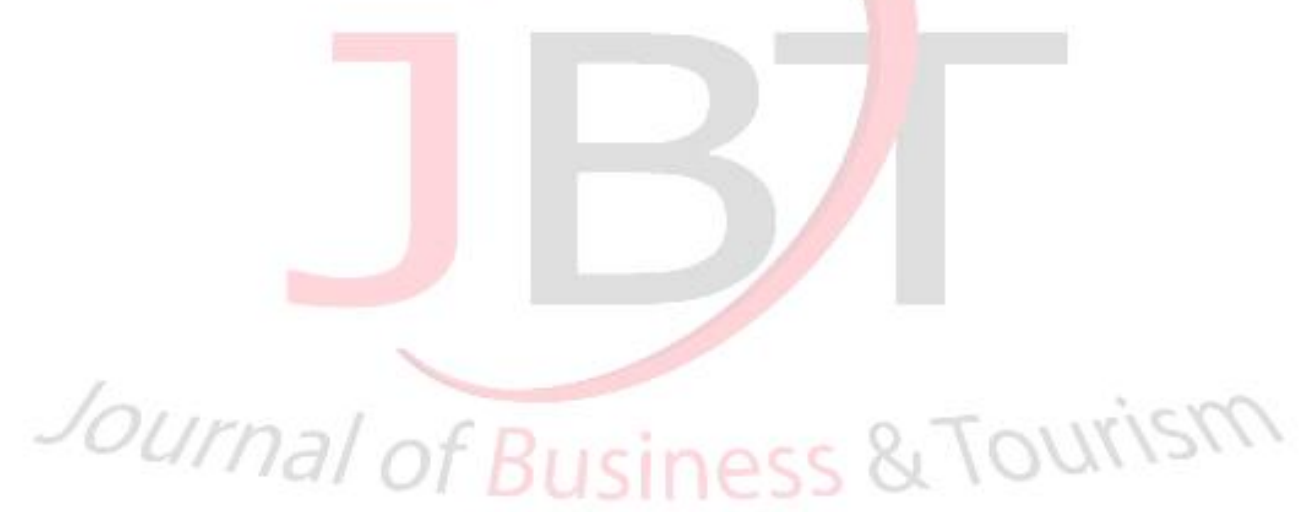

